Yüzüncü Yil Üniversitesi
Tarim Bilimleri Dergisi

Araştırma Makalesi (Research Article)

The Effect of Figs and Orange Albedo Addition on the Quality Properties of "İncir Uyutması", A Traditional Dairy Dessert

\author{
Abdullah ÇAĞLAR*1, Gökhan AKARCA ${ }^{2}$, Oktay TOMAR ${ }^{3}$, Veli GÖK ${ }^{4}$ \\ ${ }^{1,3}$ Kocaeli University, Faculty of Agriculture and Natural Science, Arslanbey Campus, 41285, Kocaeli, Turkey \\ ${ }^{2}$ Kocatepe University, Faculty of Engineering, Department of Food Engineering, 03200, Afyonkarahisar, Turkey \\ ${ }^{4}$ Ahmet Ipek Meat Company, Organized Industrial Site, 03200, Afyonkarahisar, Turkey \\ ${ }^{1}$ https://orcid.org/0000-0002-9716-8795 ${ }^{2}$ https://orcid.org/0000-0002-5055-2722 ${ }^{3}$ https://orcid.org/0000-0001-5761-7157 \\ ${ }^{4}$ https://orcid.org/0000-0002-0244-4436 \\ *Corresponding Author: e-mail: abdullah.caglar@kocaeli.edu.tr
}

\section{Article Info}

Received: 03.04.2020

Accepted: 13.05.2020

Online Published 30.06.2020

DOI: 10.29133/yyutbd.713826

Keywords

İncir uyutmas1,

Fig,

Albedo,

Quality,

Sensory.

\begin{abstract}
In this research, "incir uyutmasi", a local dairy dessert, was produced by adding figs $(10 \%, 15 \%$ and $20 \%)$ and orange peel albedo $(0.2 \%, 0.4 \%$ and $0.6 \%)$ layer at different ratios. Produced dairy desserts were stored at $4^{\circ} \mathrm{C}$ for 7 days. As a result of the physicochemical analysis, it was determined that dry matter, viscosity, a* (redness) and $b^{*}$ (yellowness) values increased related to the increase in figs ratios whereas $\mathrm{pH}$ and $\mathrm{L}^{*}$ (lightness) values decreased $(\mathrm{p}<0.05)$. The highest viscosity value was determined to be $1325 \mathrm{cp}$ in the 20 $\mathrm{g} / \mathrm{L}$ fig and $0.6 \mathrm{~g} / \mathrm{L}$ orange peel albedo sample. The addition of figs and orange peel albedos had no significant effect on the microbiological values ( $p>0.05$ ) whereas the total aerobic mesophilic and psychrophilic bacteria counts increased during storage $(\mathrm{p}<0.05)$. Yeast $/ \mathrm{mold}$ counts of the samples increased during storage $(\mathrm{p}<0.05)$. The highest increase was found in the samples containing $15 \mathrm{~g} / \mathrm{L}$ figs with $2.46 \log \mathrm{CFU} / \mathrm{g}$ and $0.6 \mathrm{~g} / \mathrm{L}$ orange peel albedo. As a result of sensory analyses, the increase in figs ratio was found to be effective on aroma and texture $(\mathrm{p}<0.05)$. The addition of orange peel albedo was found to have a significant effect on the aroma scores of the samples, however, it had no significant effects on the texture $(p<0.05)$. Overall evaluation scores increased during the first 5 days of the storage however decreased in the further days $(\mathrm{p}<0.05)$. The samples which received the highest sensory scores were $20 \mathrm{~g} / \mathrm{L}$ figs and $0.6 \mathrm{~g} / \mathrm{L}$ orange peel albedo sample.
\end{abstract}

\title{
Geleneksel Bir Süt Tatısı Olan İncir Uyutmasının Kalite Özellikleri Üzerine, İncir ve Portakal Albedosu İlavesinin Etkisi
}

\section{Makale Bilgileri}

Geliș: 03.04.2020

Kabul: 13.05 .2020

Online Yayınlanma 30.06.2020

DOI: 10.29133/yyutbd.713826

\section{Anahtar kelimeler}

İncir Uyutmas1,

İncir,

Albedo,

Kalite,

Duyusal.
Öz: Bu araştırmada, yöresel bir süt tatlısı olan “incir uyutması”, farklı oranlarda incir (\%10, \%15 ve \%20) ve portakal kabuğu albedo tabakası (\%0.2, \%0.4 ve \%0.6) ilavesi ile üretilmiştir. Üretilen süt tatlıları $4^{\circ} \mathrm{C}$ 'de 7 gün süre ile depolanmıştır. Fizikokimyasal analizler sonucunda incir miktarındaki artışa bağlı olarak kuru madde ve viskozite ile $a^{*}$ (kırmızılık) ve b* (sarılık) değerlerinde artış belirlenmesine karşın, $\mathrm{pH}$ ve $\mathrm{L}^{*}$ (aydınlık) değerinin ise azalma tespit edilmiştir $(\mathrm{p}<0.05)$. Depolama sonunda en yüksek viskozite değeri $1325 \mathrm{cp}$ ile $20 \mathrm{~g} / \mathrm{L}$ oranında incir ve $0.6 \mathrm{~g} / \mathrm{L}$ oranında portakal kabuğu albedosu ilave edilen örneklerde olduğu belirlenmiştir. İncir miktarı ve portakal kabuğu ilavesinin mikrobiyolojik değerlere önemli bir etkisinin olmadığı, buna karşın toplam aerobik mezofilik ve psikrofilik bakteri sayılarının depolama boyunca 
arttığını belirlenmiştir $(\mathrm{p}<0.05)$. Örneklerin maya küf sayılarında da depolama süresince artış meydana gelmiştir $(\mathrm{p}<0.05)$ en fazla artış $2.46 \log \mathrm{kob} / \mathrm{g}$ ile 15 $\mathrm{g} / \mathrm{L}$ süt oranında incir ve $0.6 \mathrm{~g} / \mathrm{L}$ süt oranında portakal kabuğu albedosu ilave edilen örneklerde olduğu belirlenmiştir. Duyusal analizler sonucunda, incir miktarı artışının, aroma ve tekstür üzerinde etkili olduğu belirlenmiştir $(\mathrm{p}<0.05)$. Portakal kabuğu albedosu ilavesi örneklerin aroma puanları üzerine önemli etkisi olduğu, yapı üzerinde ise önemli bir etkisinin olmadığı tespit edilmiştir $(\mathrm{p}<0.05)$. Genel beğeni puanları depolama süresinin ilk 5. günü boyunca artış göstermesine karşın takip eden günlerde azalmıştır $(\mathrm{p}<0.05)$. Duyusal olarak en beğenilen örneklerin $20 \mathrm{~g} / \mathrm{L}$ süt oranında incir ve $0.6 \mathrm{~g} / \mathrm{L}$ süt oranında portakal kabuğu albedosu içeren örnekler olduğu tespit edilmiştir.

\section{Introduction}

In Turkey, there are many types of desserts produced by using different raw materials, additives, process and storage conditions (Ayar et al., 2009). Today, with the rapid changes in lifestyle and eating habits and the increase in the number of consumers who pay attention to their health and physical appearance, heavy desserts such as sherbet, viscous desserts and pastry desserts have been replaced by dairy desserts (Kalitekin, 2015). Dairy desserts are lighter, easier to digest, and have higher nutritional values than pastry and syrup desserts (Ayar et al., 2009).

Dairy desserts are prepared by boiling milk with sugar and thickening ingredients (Hut, 2012). Although there are many types of dairy desserts, commercially most common dairy desserts in Turkey are sütlaç, kazandibi, muhallebi and güllaç (Secim, 2011).

One of the desserts that have attracted much attention in recent years and have not been commercially produced yet is "incir uyutması". İncir uyutması is a dairy dessert produced by the Turks in Anatolia and Central Asia. Its composition mainly comprises milk and figs (Ayar et al., 2009; Hut and Ayar, 2013).

Turkey has a great potential in fruit culture (Yavıç et al., 2016). One of these fruits, Figs (Ficus carica L.) is a species belonging to the Moraceae family (Caliskan, 2012) and it contains many wild and culture subspecies (Atik, 2012). In the world, especially in tropical areas, there are approximately 600 species but the most important species in terms of fruit is Ficus carica L., the Anatolian figs (Gorunmezoglu, 2008).

This study aimed to investigate the physicochemical microbiological and sensory properties of incir uyutmas produced by adding figs $(10 \%, 15 \%$ and $20 \%)$ and orange peel albedo $(0.2 \%, 0.4 \%$, and $0.6 \%)$ at different ratios during the 7 -day storage period.

\section{Materials and Methods}

\subsection{Material}

Raw cow's milk (pH 6.64 $\pm 0.15 \%$, fat $3.72 \pm 0.35 \%$, non-fat dry matter $7.8 \pm 0.14 \%$, protein $2.96 \pm 0.28 \%$ and density $1.028 \pm 0.04 \mathrm{~g} / \mathrm{cm}^{3}$ ),figs (Ficus alba L.) (in $100 \mathrm{~g}$ figs; sugar $51.8 \pm 1.66 \mathrm{~g}$, protein $3.34 \pm 0.38 \mathrm{~g}$, fat $0.84 \pm 0.03 \mathrm{~g}$, Ca $121 \pm 4.36 \mathrm{mg}, \mathrm{P} 148 \pm 6.54 \mathrm{mg}, \mathrm{Mg} 77.45 \pm 2.21 \mathrm{mg}$, and Fe $2.8 \pm 0.87 \mathrm{mg}$ ) and orange (Citrus sinensis L.) were obtained from the local markets in Afyon. Albedo peels of oranges were obtained by peeling the orange, separation of the white parts and drying the albedo in the shade and grinding to powder at room temperature.

\subsection{Figs dessert production}

Traditional incir uyutmas1 production was carried out by modifying the method explained by Hut and Ayar (2013). Accordingly, $10 \mathrm{~L}$ raw milk was taken and heat-treated at $90^{\circ} \mathrm{C}$ for 10 minutes. Figs were cleaned, sorted, then cut into small slices and dried in the shade at room temperature, then passed through a meat grinder (grinder mirror no. 12) and homogenized. After peeling the orange, the inner white peel parts (albedo) were separated, and then albedo was dried in the shade at room temperature and then shredded and powdered in the blender (Waring 8011, USA). A portion of the 
milk was transferred to a large tray and figs (10\%, 15\% and 20\%) was added. Figs are crushed thoroughly in milk with the help of a large wooden spoon. Then, the rest of the milk was transferred to the tray and orange peel albedos $(0.2 \%, 0.4 \%$, and $0.6 \%)$ were added to the formulation in appropriate ratios and mixed with the milk. After adding figs and orange peel albedos, the samples were placed in glass jars and kept at $40^{\circ} \mathrm{C}$ for 1 hour, then rested for half an hour under room conditions and stored at $4^{\circ} \mathrm{C}$.

\subsection{Physical and chemical analysis}

The $\mathrm{pH}$ values of the milk used in the study were determined with Ohaus (ST 5000, USA). Also, fat, dry matter and density analyzes were made according to AOAC (2016). Kjeldahl method and Lane-Eynon method were used to the determination of protein and sugar (\%) amounts of fig samples (AOAC 2016). Contents of minerals were measured using an Inductively Coupled Plasma Atomic Emission Spectrometer (ICP-AES) (Model Agilent 7500c, Agilent Technologies, USA).

The $\mathrm{pH}$ values of figs dessert samples were determined according to Ohaus (ST 5000, USA) and AOAC 981.12 (AOAC, 2016). Viscosity values of the samples were determined using a Brookfield viscometer (Mod-RVDV++, Brookfield Engineering Laboratories, Stoughton Mass., USA) with spindle no: 6 at the rotational speed of $100 \mathrm{rpm}$ in 30 seconds (Hut, 2012).

Color analyses of the samples were performed using a colorimeter (Konika Minolta Chroma Meter CR-400) and L*, a* and b* values were measured (Akarca et al., 2015). Dry matter analyses of samples were performed according to Hunt and Ayar (2013) using a RADWAG MAC 110/NH Moisture analyzer.

\subsection{Microbiological analysis}

Total aerobic mesophilic bacteria (TAMB) and total aerobic psychrophilic bacteria (TAPB) count analyzes were performed by the streak plate method using Plate Count Agar (PCA) (Merck 1.05463, Germany). Inoculated Petri dishes were allowed to incubate for TAMB count at $30^{\circ} \mathrm{C}$ for 48 72 hours and TAPB count at $4^{\circ} \mathrm{C}$ for 5-7 days under aerobic conditions (Halkman, 2005; ISO, 2013a; ISO, 2013b). For yeast/mold count analysis, Rose Bengal Chloramphenicol Agar (Merck 1.00467, Germany) (RBC) was used and the inoculated Petri dishes were incubated at $22^{\circ} \mathrm{C}$ for 5-7 days under aerobic conditions (ISO, 2008). Violet Red Bile Agar (Merck 1.01406, Germany) was used for the enumeration of total coliform group bacteria (TCGB). Accordingly, Petri dishes were allowed to incubate for $24-48$ hours at $30^{\circ} \mathrm{C}$ under aerobic conditions (ISO, 1991).

\subsection{Sensory evaluation}

For the sensory evaluation of the samples, the sensory test parameters were used by modifying the scoring cards by Akarca et al. (2016) and the differences were determined by the scoring system on a scale. In the sensory evaluations, 24 panelists were involved in the sensory analysis panel and 12 dessert samples were presented in different ways in each panel. Dessert samples were scored from 1 to 9 for color-appearance, odor-taste, texture-consistency and overall evaluation. Accordingly, the scoring grades were 1-3 (unacceptable), 4-5 (acceptable), 6-7 (good), 8-9 (very good) (Anonymous, 2012; Onogur and Elmaci, 2012).

\subsection{Statistical evaluation}

SPSS 20.0 (SPSS Inc, USA) statistical software package program was used to statistically analyze the results. The data obtained from the analyses were evaluated by variance analysis technique in a randomized block experiment design. The Duncan test was adopted to determine the level of difference between groups. 


\section{Results and Discussion}

The ratios of figs and orange albedo added to incir uyutmas1 samples and the sample codes are shown in Table 1. On the 1st day of the storage, the lowest $\mathrm{pH}$ value in the samples was determined to be 5.66 in $\mathrm{U} 22$ whereas the highest $\mathrm{pH}$ value was determined to be 6.39 in $\mathrm{K} 1$. On the last day of storage, the lowest $\mathrm{pH}$ was determined in the U32 sample with 5.46 whereas the highest $\mathrm{pH}$ was determined in K1 sample with 6.5 (Table 2). According to the results of variance analysis (Table 3), the addition of figs and orange peel albedo was statistically very significant $(p<0.0001)$ while the storage period was significant $(\mathrm{p}<0.05)$. Also, fig $\mathrm{x}$ orange, orange $\mathrm{x}$ storage and fig $\mathrm{x}$ orange $\mathrm{x}$ storage interactions were very significant $(\mathrm{p}<0.01)$ while fig $\mathrm{x}$ storage interaction was significant $(\mathrm{p}<0.05$; Table 3). Hut and Ayar (2013) have reported that they determined the $\mathrm{pH}$ values of fig desserts between 5.92 and 6.15 .

Table 1 . The ratios of figs and orange peel albedo added to the incir uyutmasi samples and the sample codes

\begin{tabular}{lll}
\hline Sample Code & Figs Ratio (g/L milk) & Albedo Ratio (g/L milk) \\
\hline K1 & 10 & --- \\
U11 & 10 & 0.2 \\
U12 & 10 & 0.4 \\
U13 & 10 & 0.6 \\
K2 & 15 & --- \\
U21 & 15 & 0.2 \\
U22 & 15 & 0.4 \\
U23 & 15 & 0.6 \\
K3 & 20 & --- \\
U31 & 20 & 0.2 \\
U32 & 20 & 0.4 \\
U33 & 20 & 0.6 \\
\hline
\end{tabular}

The viscosity of the final product increased as the ratios of figs and orange albedo increased, $(\mathrm{p}<0.05)$. At the beginning of storage, the lowest viscosity value was found in the K1 sample with 480 cp whereas the highest value was found in the U33 sample with 1425 cp (Table 4). Although the viscosity values of the samples increased during the first 5 days, they decreased on the 7th day $(\mathrm{p}<0.05)$. On the 7th day of the storage, the lowest viscosity value was determined in the K1 sample with $725 \mathrm{cp}$ whereas the highest was determined in the U33 sample with $1325 \mathrm{cp}$. The results obtained in this study were in line with the results reported by Ayar (2013) and Kalitekin (2015).

Table 2. Changes in the $\mathrm{pH}$ values of figs dessert samples during storage

\begin{tabular}{llccc}
\hline Sample & & \multicolumn{3}{c}{$\begin{array}{c}\mathrm{pH} \\
\text { Storage Period (days) }\end{array}$} \\
\hline K1 & 1 & 3 & 5 & 7 \\
U11 & $6.39 \pm 0.01^{\mathrm{Ca}}$ & $6.42 \pm 0.01^{\mathrm{Ba}}$ & $6.36 \pm 0.03^{\mathrm{Ca}}$ & $6.55 \pm 0.02^{\mathrm{Aa}}$ \\
U12 & $6.23 \pm 0.01^{\mathrm{Bab}}$ & $6.12 \pm 0.04^{\mathrm{Cc}}$ & $6.14 \pm 0.03^{\mathrm{Cc}}$ & $6.33 \pm 0.02^{\mathrm{Ab}}$ \\
U13 & $6.18 \pm 0.01^{\mathrm{Bb}}$ & $6.18 \pm 0.01^{\mathrm{Bc}}$ & $6.22 \pm 0.01^{\mathrm{Ab}}$ & $6.24 \pm 0.01^{\mathrm{Ac}}$ \\
K2 & $6.08 \pm 0.01^{\mathrm{Dbc}}$ & $6.27 \pm 0.02^{\mathrm{Ab}}$ & $6.20 \pm 0.01^{\mathrm{Bb}}$ & $6.15 \pm 0.03^{\mathrm{Cd}}$ \\
U21 & $5.86 \pm 0.11^{\mathrm{Ccd}}$ & $5.77 \pm 0.05^{\mathrm{Dg}}$ & $6.20 \pm 0.01^{\mathrm{Ab}}$ & $6.16 \pm 0.01^{\mathrm{Bd}}$ \\
U22 & $6.10 \pm 0.02^{\mathrm{Bb}}$ & $6.02 \pm 0.04^{\mathrm{Cd}}$ & $5.93 \pm 0.16^{\mathrm{De}}$ & $6.19 \pm 0.01^{\mathrm{Acd}}$ \\
U23 & $5.66 \pm 0.13^{\mathrm{Cf}}$ & $5.56 \pm 0.08^{\mathrm{Du}}$ & $5.95 \pm 0.01^{\mathrm{Bf}}$ & $6.10 \pm 0.14^{\mathrm{Ae}}$ \\
K3 & $5.75 \pm 0.13^{\mathrm{Ce}}$ & $6.15 \pm 0.04^{\mathrm{Ac}}$ & $6.01 \pm 0.06^{\mathrm{Ad}}$ & $5.50 \pm 0.03^{\mathrm{Dg}}$ \\
U31 & $5.72 \pm 0.19^{\mathrm{Ce}}$ & $5.98 \pm 0.01^{\mathrm{Be}}$ & $6.02 \pm 0.01^{\mathrm{Ad}}$ & $5.97 \pm 0.01^{\mathrm{Bf}}$ \\
U32 & $5.92 \pm 0.04^{\mathrm{Bc}}$ & $5.88 \pm 0.01^{\mathrm{Cf}}$ & $5.81 \pm 0.04^{\mathrm{ABef}}$ & $5.78 \pm 0.01^{\mathrm{Dfg}}$ \\
U33 & $5.83 \pm 0.06^{\mathrm{Acd}}$ & $5.78 \pm 0.01^{\mathrm{Bg}}$ & $5.36 \pm 0.01^{\mathrm{Cg}}$ & $5.46 \pm 0.02^{\mathrm{Cgh}}$ \\
\hline
\end{tabular}

a-1 $(\downarrow)$ : Values with the same capital letters in the same column for each analysis differ significantly $(\mathrm{p}<0.05)$.

A-D $(\rightarrow)$ : Values with the same capital letters in the same rows for each analysis differ significantly $(p<0.05)$.

According to the results of the variance analysis, the effect of figs addition was statistically very significant $(p<0.0001)$ while the effect of orange albedo addition and storage period was very significant $(\mathrm{p}<0.001)$. Besides, figs $\mathrm{x}$ orange and figs $\mathrm{x}$ storage time interactions were also statistically significant $(\mathrm{p}<0.05$; Table 3$)$. 
Table 3. The results of the analysis of variance for the physicochemical analysis of figs dessert samples (p* value)

\begin{tabular}{|c|c|c|c|c|c|c|}
\hline Source of Variance & $\mathrm{pH}$ & Viscosity & Dry Matter & $\mathrm{L}^{*}$ & $a^{*}$ & $b^{*}$ \\
\hline Figs & $<0.0001 * * *$ & $<0.0001^{* * *}$ & $<0.0001 * * *$ & $<0.0001^{* * *}$ & $<0.0001^{* * *}$ & $<0.0001 * * *$ \\
\hline Albedo & $<0.0001 * * *$ & $0.0021 * *$ & $0.0048 * *$ & $0.041^{*}$ & $0.002 * *$ & $0.0021^{* *}$ \\
\hline Storage & $0.019 *$ & $0.0098 * *$ & $0.012 *$ & $0.0062 * *$ & $0.0011^{* *}$ & $0.0014 * *$ \\
\hline Figs x Albedo & $0.0021 * *$ & $0.035 *$ & $0.345 n s$ & $0.014 *$ & $0.025^{*}$ & $0.0089 * *$ \\
\hline Figs $\mathrm{x}$ Storage & $0.015^{*}$ & $0.045^{*}$ & $0.098 \mathrm{~ns}$ & $0.021 *$ & $0.011 *$ & $0.343 n s$ \\
\hline Albedo x Storage & $0.0065 * *$ & $0.567 \mathrm{~ns}$ & $0.213 \mathrm{~ns}$ & $0.232 \mathrm{~ns}$ & $0.018 *$ & $0.0017 * *$ \\
\hline Figs x Albedo x Storage & $0.0023 * *$ & $0.128 \mathrm{~ns}$ & $0.219 \mathrm{~ns}$ & $0.041 *$ & $0.031 *$ & $0.041 *$ \\
\hline
\end{tabular}

${ }^{*} \mathrm{p}<0.05,{ }^{* *} \mathrm{p}<0.01,{ }^{* * *} \mathrm{p}<0.0001$, ns: Statistically not significant.

Table 4. Changes in the viscosity values of figs dessert samples during storage

\begin{tabular}{lllll}
\hline Sample & & \multicolumn{2}{c}{$\begin{array}{c}\text { Viscosity } \\
\text { Storage Period (days) }\end{array}$} \\
\hline K1 & 1 & 3 & 5 & 7 \\
U11 & $480 \pm 14.14^{\mathrm{Dg}}$ & $555 \pm 63.64^{\mathrm{C}}$ & $725 \pm 176.78^{\mathrm{Aef}}$ & $725 \pm 106.07^{\mathrm{Bd}}$ \\
U12 & $515 \pm 49.50^{\mathrm{Df}}$ & $675 \pm 106.07^{\mathrm{Cg}}$ & $725 \pm 106.07^{\mathrm{Bg}}$ & $750 \pm 141.42^{\mathrm{Ad}}$ \\
U13 & $525 \pm 106.07^{\mathrm{Df}}$ & $615 \pm 49.50^{\mathrm{Ch}}$ & $850 \pm 70.71^{\mathrm{Aef}}$ & $800 \pm 70.71^{\mathrm{Bde}}$ \\
K2 & $630 \pm 113.14^{\mathrm{Be}}$ & $650 \pm 141.42^{\mathrm{Bgh}}$ & $800 \pm 70.71^{\mathrm{Af}}$ & $825 \pm 106.07^{\mathrm{Ac}}$ \\
U21 & $825 \pm 106.7^{\mathrm{Cd}}$ & $810 \pm 56.57^{\mathrm{Cef}}$ & $1000 \pm 141.42^{\mathrm{Ab}}$ & $900 \pm 70.71^{\mathrm{Bbc}}$ \\
U22 & $600 \pm 70.71^{\mathrm{Cde}}$ & $800 \pm 70.71^{\mathrm{Bf}}$ & $960 \pm 84.85^{\mathrm{Ade}}$ & $900 \pm 141.42^{\mathrm{Abc}}$ \\
U23 & $800 \pm 70.71^{\mathrm{Cd}}$ & $905 \pm 77.78^{\mathrm{ABe}}$ & $1050 \pm 141.42^{\mathrm{Ad}}$ & $850 \pm 141.42^{\mathrm{BCc}}$ \\
K3 & $1000 \pm 141^{\mathrm{Ab}}$ & $925 \pm 106.07^{\mathrm{Bd}}$ & $1125 \pm 176.78^{\mathrm{Acd}}$ & $950 \pm 70.71^{\mathrm{Bbc}}$ \\
U31 & $945 \pm 134.35^{\mathrm{Bbc}}$ & $1175 \pm 35.36^{\mathrm{ABc}}$ & $1275 \pm 106.07^{\mathrm{Ac}}$ & $1025 \pm 106.07^{\mathrm{Bb}}$ \\
U32 & $925 \pm 35.36^{\mathrm{Cc}}$ & $1325 \pm 106.07^{\mathrm{Ab}}$ & $1300 \pm 70.71^{\mathrm{Ab}}$ & $1175 \pm 35.36^{\mathrm{Bb}}$ \\
U33 & $1050 \pm 212.13^{\mathrm{Cb}}$ & $1325 \pm 176.78^{\mathrm{Ab}}$ & $1375 \pm 106.07^{\mathrm{Aab}}$ & $1250 \pm 70.71^{\mathrm{Bab}}$ \\
\hline
\end{tabular}

a-1 $(\downarrow)$ : Values with the same capital letters in the same column for each analysis differ significantly $(\mathrm{p}<0.05)$.

A-D $(\rightarrow)$ : Values with the same capital letters in the same rows for each analysis differ significantly $(\mathrm{p}<0.05)$

Dry matter values increased in all samples during storage $(\mathrm{p}<0.05)$. On the 1 st day of the storage, the lowest dry matter value in the samples was determined to be $16.41 \pm 0.54$ in K1 whereas the highest value was determined to be $24.75 \pm 0.09$ in U33. On the last day of storage, the lowest dry matter was determined in the $\mathrm{K} 1$ sample with $17.03 \pm 0.57$ whereas the highest dry matter was determined in the U33 sample with $25.22 \pm 0.69$ (Table 5). According to the results of variance analysis (Table 3$)$, the addition of figs was statistically very significant $(\mathrm{p}<0.0001)$ while the addition of orange very significant $(\mathrm{p}<0.01)$ and the storage period was significant $(\mathrm{p}<0.05$; Table 3$)$.

Table 5. Changes in the dry matter of figs dessert samples during storage

\begin{tabular}{|c|c|c|c|c|}
\hline \multirow[t]{2}{*}{ Sample } & \multicolumn{4}{|c|}{$\begin{array}{c}\text { Dry Matter } \\
\text { Storage Period (days) }\end{array}$} \\
\hline & 1 & 3 & 5 & 7 \\
\hline K1 & $16.41 \pm 0.54^{\mathrm{Cl}}$ & $16.78 \pm 0.54^{\mathrm{BCj}}$ & $16.95 \pm 1.52^{\mathrm{ABj}}$ & $17.03 \pm 0.57^{\mathrm{A} 1}$ \\
\hline U11 & $16.86 \pm 0.45^{\mathrm{Dk}}$ & $17.07 \pm 0.37^{\mathrm{C} 1}$ & $18.05 \pm 1.04^{\mathrm{B} 1}$ & $18.40 \pm 0.44^{\mathrm{Ah}}$ \\
\hline U12 & $17.61 \pm 0.03^{\mathrm{Cj}}$ & $18.18 \pm 1.53^{\mathrm{Bh}}$ & $18.43 \pm 0.02^{\mathrm{ABh}}$ & $18.62 \pm 0.93^{\mathrm{Ag}}$ \\
\hline U13 & $17.92 \pm 0.59^{\mathrm{C} 1}$ & $18.16 \pm 0.18^{\mathrm{Bh}}$ & $18.36 \pm 0.10^{\mathrm{ABh}}$ & $18.48 \pm 1.29^{\mathrm{Ah}}$ \\
\hline K2 & $18.05 \pm 0.08^{\mathrm{Dh}}$ & $18.67 \pm 0.45^{\mathrm{Cg}}$ & $20.10 \pm 0.16^{\mathrm{Bg}}$ & $20.93 \pm 0.14^{\mathrm{Af}}$ \\
\hline U21 & $19.07 \pm 0.43^{\mathrm{Cg}}$ & $19.97 \pm 0.98^{\mathrm{Bf}}$ & $20.06 \pm 0.18^{\mathrm{ABg}}$ & $20.11 \pm 0.04^{\mathrm{Ag}}$ \\
\hline U22 & $19.30 \pm 1.36^{\mathrm{Cf}}$ & $20.19 \pm 0.06^{\mathrm{Be}}$ & $20.47 \pm 0.22^{\mathrm{ABe}}$ & $20.77 \pm 1.44^{\mathrm{Ae}}$ \\
\hline U23 & $20.02 \pm 0.26^{\mathrm{Ce}}$ & $20.11 \pm 0.82^{\text {ВСe }}$ & $20.28 \pm 0.25^{\mathrm{Bf}}$ & $20.82 \pm 0.42^{\mathrm{Ae}}$ \\
\hline K3 & $23.37 \pm 0.04^{\mathrm{Cd}}$ & $23.46 \pm 1.49^{\mathrm{BCd}}$ & $23.73 \pm 0.35^{\mathrm{ABd}}$ & $23.99 \pm 0.37^{\mathrm{Ad}}$ \\
\hline U31 & $23.55 \pm 0.06^{\mathrm{Dc}}$ & $23.81 \pm 0.51^{\mathrm{Cc}}$ & $24.02 \pm 1.05^{\mathrm{Bc}}$ & $24.54 \pm 0.52^{\mathrm{Ac}}$ \\
\hline U32 & $24.17 \pm 0.19^{\mathrm{Db}}$ & $24.43 \pm 0.54^{\mathrm{Cb}}$ & $24.67 \pm 0.83^{\mathrm{Bb}}$ & $24.89 \pm 0.14^{\mathrm{Ab}}$ \\
\hline U33 & $24.75 \pm 0.09^{\text {САа }}$ & $24.90 \pm 0.87^{\text {ВСа }}$ & $25.19 \pm 0.43^{\text {Аа }}$ & $25.22 \pm 0.69^{\mathrm{Aa}}$ \\
\hline
\end{tabular}

a-l $(\downarrow)$ : Values with the same capital letters in the same column for each analysis differ significantly $(\mathrm{p}<0.05)$.

A-D $(\rightarrow)$ : Values with the same capital letters in the same rows for each analysis differ significantly $(\mathrm{p}<0.05)$

The amount of dry matter determined in this study is similar to Ayar et al. 2009 but lower than Hut 2012. The current differences vary depending on the number of figs used and the addition of sugar and other ingredients in the formulation. 
$\mathrm{L}^{*}$ values of figs dessert samples increased in the first three days of storage however decreased in the following days $(\mathrm{p}<0.05)$. At the beginning and the end of storage, the highest $\mathrm{L}^{*}$ values were determined in the K1 sample with 75.14 and 71.32, respectively (Table 6). It was determined that the increase in figs and albedo ratios added to the samples decreased the $\mathrm{L}^{*}$ value $(p<0.05)$. According to the variance analysis results (Table 3), the effect of the addition of figs was statistically very significant $(p<0.0001)$ while the effect of the addition of the orange peel albedo was found to be significant $(p<0.05)$. The effect of storage on the samples was determined to be very significant $(\mathrm{p}<0.01)$. On the other hand, fig $\mathrm{x}$ orange, fig $\mathrm{x}$ storage and fig $\mathrm{x}$ orange $\mathrm{x}$ storage interactions were found to be significant at $\mathrm{p}<0.05$. The $\mathrm{a}^{*}$ values of the samples increased during the storage period $(\mathrm{p}<0.05)$.

On the 1st and the 7th day of storage, the lowest $\mathrm{a}^{*}$ value was found in the K1 sample with $3.26 \pm 0.18$ and $3.59 \pm 0.04$, respectively, whereas the highest $a^{*}$ value was found in the U33 sample with $4.25 \pm 0.13$ and $5.10 \pm 0.06$, respectively (Table 7). It was determined that $\mathrm{a}^{*}$ value increased as the ratios of figs and orange peel albedo increased $(p<0.05)$. According to the results of the variance analysis (Table 3), the addition of figs was statistically very significant $(\mathrm{p}<0.0001)$ while the addition of the orange peel albedo was found to be significant $(p<0.05)$. In addition, figs $x$ storage, figs $x$ orange peel albedo and figs $x$ storage $x$ orange peel albedo interactions were significant at $\mathrm{p}<0.01$ level while orange peel albedo $x$ fig interaction was found to be significant at $\mathrm{p}<0.05$ level.

It was determined that $b^{*}$ values of samples increased during storage $(\mathrm{p}<0.05)$. The lowest $b^{*}$ values at the beginning and the end of the storage was determined in the K1 sample with $5.82 \pm 0.19$ and $6.34 \pm 0.08$, respectively, while the highest $b^{*}$ values on the first and last day of storage were determined in the U33 samples with $12.48 \pm 0,21$ and $13.57 \pm 0.40$, respectively (Table 8). As the fig and albedo layer added to the samples increased, $b^{*}$ value increased $(p<0.05)$. According to the variance analysis results (Table 3$)$, the effect of the addition of figs was statistically very significant $(p<0.0001)$ while the effect of the addition of the orange peel albedo was found to be significant $(p<0.05)$.

Table 6. Changes in the $\mathrm{L}^{*}$ values of figs dessert samples during storage

\begin{tabular}{|c|c|c|c|c|}
\hline \multirow[t]{2}{*}{ Sample } & \multicolumn{4}{|c|}{$\begin{array}{c}\mathrm{L}^{*} \\
\text { Storage Period (days) }\end{array}$} \\
\hline & 1 & 3 & 5 & 7 \\
\hline K1 & $75.14 \pm 0.10^{\mathrm{Aa}}$ & $75.79 \pm 1.19^{\mathrm{Aa}}$ & $73.32 \pm 0.30^{\mathrm{ABa}}$ & $71.32 \pm 1.62^{\mathrm{Bab}}$ \\
\hline U11 & $72.55 \pm 0.28^{\mathrm{Ab}}$ & $68.88 \pm 0.57^{\mathrm{Bc}}$ & $70.94 \pm 1.31^{\mathrm{ABab}}$ & $69.02 \pm 0.37^{\mathrm{Bb}}$ \\
\hline U12 & $71.17 \pm 0.06^{\mathrm{Abc}}$ & $70.07 \pm 2.67^{\mathrm{Ab}}$ & $69.81 \pm 0.27^{\mathrm{Bb}}$ & $70.04 \pm 0.85^{\mathrm{Ab}}$ \\
\hline U13 & $73.76 \pm 1.48^{\mathrm{ABb}}$ & $75.80 \pm 0.23^{\mathrm{Aa}}$ & $70.55 \pm 1.77^{\mathrm{Bab}}$ & $72.13 \pm 0.18^{\mathrm{ABa}}$ \\
\hline K2 & $68.10 \pm 0.45^{\mathrm{Ac}}$ & $67.02 \pm 3.82^{\mathrm{Ac}}$ & $68.21 \pm 1.21^{\mathrm{Ab}}$ & $68.22 \pm 0.87^{\mathrm{Abc}}$ \\
\hline U21 & $69.51 \pm 1.29^{\mathrm{ABc}}$ & $70.16 \pm 1.20^{\mathrm{Ab}}$ & $65.84 \pm 0.59^{\mathrm{Cc}}$ & $67.62 \pm 1.63^{\mathrm{Bc}}$ \\
\hline U22 & $70.42 \pm 2.03^{\mathrm{Abc}}$ & $68.64 \pm 0.08^{\mathrm{ABc}}$ & $68.15 \pm 1.27^{\mathrm{ABb}}$ & $67.83 \pm 0.79^{\mathrm{Bc}}$ \\
\hline $\mathrm{U} 23$ & $71.11 \pm 0.04^{\mathrm{Abc}}$ & $67.82 \pm 2.06^{\mathrm{Bc}}$ & $66.53 \pm 3.67^{\mathrm{Bbc}}$ & $64.36 \pm 0.39^{\mathrm{Cd}}$ \\
\hline K3 & $66.70 \pm 0.15^{\text {Acd }}$ & $64.51 \pm 0.00^{\mathrm{Bd}}$ & $61.60 \pm 0.03^{\mathrm{BC}}$ & $60.58 \pm 0.19^{\mathrm{Ce}}$ \\
\hline U31 & $65.66 \pm 0.41^{\mathrm{Ad}}$ & $63.09 \pm 0.89^{\mathrm{Bd}}$ & $62.73 \pm 1.33^{\mathrm{Be}}$ & $60.46 \pm 0.35^{\mathrm{Ce}}$ \\
\hline U32 & $67.64 \pm 0.94^{\mathrm{Ac}}$ & $66.86 \pm 2.77^{\mathrm{Ac}}$ & $62.32 \pm 2.77^{\mathrm{Be}}$ & $56.84 \pm 0.37^{\mathrm{Cg}}$ \\
\hline U33 & $66.67 \pm 2.40^{\text {Acd }}$ & $65.73 \pm 0.04^{\mathrm{ABcd}}$ & $64.15 \pm 0.78^{\mathrm{Bd}}$ & $59.49 \pm 0.79^{\mathrm{Cf}}$ \\
\hline
\end{tabular}

a-g $(\downarrow)$ : Values with the same capital letters in the same column for each analysis differ significantly $(\mathrm{p}<0.05)$.

A-C $(\rightarrow)$ : Values with the same capital letters in the same rows for each analysis differ significantly $(\mathrm{p}<0.05)$. 
Table 7. Changes in the $\mathrm{a}^{*}$ values of figs dessert samples during storage

\begin{tabular}{llccc}
\hline Sample & \multicolumn{3}{c}{$\begin{array}{c}\mathrm{a}^{*} \\
\text { Storage Period (days) }\end{array}$} \\
\hline K1 & 1 & 3 & 5 & 7 \\
U11 & $3.26 \pm 0.18^{\mathrm{Df}}$ & $3.34 \pm 0.06^{\mathrm{Cf}}$ & $3.55 \pm 0.02^{\mathrm{Bg}}$ & $3.59 \pm 0.04^{\mathrm{Al}}$ \\
U12 & $3.36 \pm 0.05^{\mathrm{De}}$ & $3.62 \pm 0.15^{\mathrm{Ce}}$ & $3.74 \pm 0.11^{\mathrm{Bf}}$ & $3.87 \pm 0.10^{\mathrm{Ah}}$ \\
U13 & $3.68 \pm 0.01^{\mathrm{Dd}}$ & $3.71 \pm 0.14^{\mathrm{Cde}}$ & $3.76 \pm 0.08^{\mathrm{Bf}}$ & $3.92 \pm 0.18^{\mathrm{Ag}}$ \\
K2 & $3.38 \pm 0.05^{\mathrm{Ce}}$ & $3.58 \pm 0.06^{\mathrm{BCe}}$ & $3.62 \pm 0.18^{\mathrm{Bfg}}$ & $4.09 \pm 0.06^{\mathrm{Af}}$ \\
U21 & $3.85 \pm 0.16^{\mathrm{Dcd}}$ & $3.95 \pm 0.11^{\mathrm{Ccd}}$ & $4.05 \pm 0.04^{\mathrm{Be}}$ & $4.47 \pm 0.04^{\mathrm{Ae}}$ \\
U22 & $4.13 \pm 0.05^{\mathrm{Cb}}$ & $4.14 \pm 0.23^{\mathrm{Cbc}}$ & $4.18 \pm 0.06^{\mathrm{BCde}}$ & $4.43 \pm 0.04^{\mathrm{Ae}}$ \\
U23 & $4.02 \pm 0.13^{\mathrm{Cc}}$ & $4.08 \pm 0.22^{\mathrm{Cc}}$ & $4.28 \pm 0.06^{\mathrm{Bd}}$ & $4.60 \pm 0.26^{\mathrm{Ad}}$ \\
K3 & $3.77 \pm 0.11^{\mathrm{Cd}}$ & $3.79 \pm 0.04^{\mathrm{Cd}}$ & $4.32 \pm 0.03^{\mathrm{Bd}}$ & $4.62 \pm 0.13^{\mathrm{Ad}}$ \\
U31 & $4.11 \pm 0.05^{\mathrm{Db}}$ & $4.32 \pm 0.10^{\mathrm{Cab}}$ & $4.52 \pm 0.11^{\mathrm{Bc}}$ & $4.83 \pm 0.03^{\mathrm{Abc}}$ \\
U32 & $3.95 \pm 0.08^{\mathrm{Dc}}$ & $4.27 \pm 0.02^{\mathrm{Cb}}$ & $4.49 \pm 0.21^{\mathrm{Bcd}}$ & $4.77 \pm 0.14^{\mathrm{Ac}}$ \\
U33 & $3.97 \pm 0.04^{\mathrm{Dc}}$ & $4.33 \pm 0.03^{\mathrm{Cab}}$ & $4.73 \pm 0.03^{\mathrm{Bb}}$ & $4.98 \pm 0.11^{\mathrm{Ab}}$ \\
\hline
\end{tabular}

a-1 $(\downarrow)$ : Values with the same capital letters in the same column for each analysis differ significantly $(\mathrm{p}<0.05)$.

A-D $(\rightarrow)$ : Values with the same capital letters in the same rows for each analysis differ significantly $(\mathrm{p}<0.05)$.

Table 8. Changes in the $b^{*}$ values of figs dessert samples during storage

\begin{tabular}{lllll}
\hline & \multicolumn{3}{c}{$\mathrm{b}^{*}$} \\
Sample & 1 & \multicolumn{2}{c}{ Storage Period (days) } \\
\hline K1 & $5.82 \pm 0.19^{\mathrm{Dk}}$ & $5.91 \pm 0.05^{\mathrm{Cj}}$ & $6.15 \pm 0.89^{\mathrm{Bk}}$ & $6.34 \pm 0.08^{\mathrm{Al}}$ \\
$\mathrm{U} 11$ & $8.09 \pm 0.41^{\mathrm{Dj}}$ & $8.11 \pm 0.59^{\mathrm{C} 1}$ & $8.18 \pm 0.54^{\mathrm{Bj}}$ & $8.24 \pm 2.04^{\mathrm{Ah}}$ \\
U12 & $8.24 \pm 0.28^{\mathrm{Cl}}$ & $8.59 \pm 0.88^{\mathrm{Bh}}$ & $9.01 \pm 0.69^{\mathrm{Al}}$ & $9.03 \pm 0.08^{\mathrm{Ag}}$ \\
U13 & $8.30 \pm 0.09^{\mathrm{Dh}}$ & $8.75 \pm 0.09^{\mathrm{Cg}}$ & $9.55 \pm 0.41^{\mathrm{Bh}}$ & $10.02 \pm 0.13^{\mathrm{Af}}$ \\
K2 & $9.65 \pm 0.45^{\mathrm{Cg}}$ & $10.08 \pm 0.94^{\mathrm{Bf}}$ & $10.15 \pm 0.45^{\mathrm{ABg}}$ & $10.32 \pm 0.18^{\mathrm{Ae}}$ \\
U21 & $10.03 \pm 0.46^{\mathrm{Df}}$ & $10.48 \pm 0.23^{\mathrm{Ce}}$ & $11.03 \pm 0.72^{\mathrm{Bf}}$ & $11.69 \pm 0.01^{\mathrm{Ade}}$ \\
U22 & $10.07 \pm 1.77^{\mathrm{Df}}$ & $10.55 \pm 1.63^{\mathrm{Cd}}$ & $10.67 \pm 0.76^{\mathrm{Be}}$ & $11.82 \pm 0.76^{\mathrm{Ad}}$ \\
U23 & $10.15 \pm 0.98^{\mathrm{De}}$ & $10.66 \pm 0.40^{\mathrm{Cc}}$ & $11.87 \pm 0.03^{\mathrm{Bd}}$ & $12.53 \pm 0.54^{\mathrm{Ac}}$ \\
K3 & $10.52 \pm 0.20^{\mathrm{Dd}}$ & $11.56 \pm 0.43^{\mathrm{Cd}}$ & $12.28 \pm 0.04^{\mathrm{Bc}}$ & $13.12 \pm 0.35^{\mathrm{Aab}}$ \\
U31 & $11.43 \pm 0.50^{\mathrm{Dc}}$ & $11.69 \pm 0.49^{\mathrm{Cc}}$ & $12.49 \pm 0.71^{\mathrm{Bab}}$ & $13.19 \pm 0.06^{\mathrm{Aab}}$ \\
U32 & $11.90 \pm 0.28^{\mathrm{Db}}$ & $12.09 \pm 0.71^{\mathrm{Cb}}$ & $12.39 \pm 1.21^{\mathrm{Bb}}$ & $13.02 \pm 0.04^{\mathrm{Ab}}$ \\
U33 & $12.48 \pm 0.21^{\mathrm{Ca}}$ & $12.52 \pm 0.30^{\mathrm{BCa}}$ & $12.59 \pm 0.08^{\mathrm{Ba}}$ & $13.57 \pm 0.40^{\mathrm{Aa}}$ \\
\hline
\end{tabular}

a-k $(\downarrow)$ : Values with the same capital letters in the same column for each analysis differ significantly $(\mathrm{p}<0.05)$.

A-D $(\rightarrow)$ : Values with the same capital letters in the same rows for each analysis differ significantly $(\mathrm{p}<0.05)$.

Total aerobic mesophilic bacteria (TAMB) counts of fig dessert samples increased during storage ( $\mathrm{p}<0.05$; Table 9). The highest increase during the seven-day storage was $2.03 \mathrm{log} \mathrm{CFU} / \mathrm{g}$ in the K2 sample while the lowest increase was $1.07 \mathrm{log}$ CFU/g in the U23 sample.

According to the results of the variance test analysis; The effect of the addition of figs was found to be statistically very significant $(\mathrm{p}<0.01)$ while the addition of orange albedo was significant $(p<0.05)$ and the storage period was very significant $(p<0.0001)$. In addition, fig $x$ orange, orange $x$ storage interactions were statistically significant $(\mathrm{p}<0.05$; Table 10$)$.

Total aerobic psychrophilic bacteria (TAPB) counts of the samples increased during the 7-day storage $(\mathrm{p}<0.05)$. On the first day of storage, the lowest TAPB count was determined in the K1 sample with $2.03 \pm 0.08 \log$ CFU/g. On the seventh day of the storage, the highest TAPB count was determined to be $4.18 \pm 0.12 \log$ CFU/g in the U23 sample (Table 9).

The effect of the storage period was found to be very significant $(\mathrm{p}<0.0001)$. In addition, fig $\mathrm{x}$ orange interactions were found to be statistically significant $(p<0.05$; Table 10).

Yeast/mold counts of the samples increased during storage $(\mathrm{p}<0.05)$ and the highest increase was found in the U23 sample with $2.46 \mathrm{log} \mathrm{CFU} / \mathrm{g}$ (Table 9). Yeast/mold counts of the samples determined in our research were similar to those reported by Hut and Ayar (2013) whereas higher than those reported by Ayar (2013). The differences were associated with the high microbial loads of the materials used in our research (fig, orange peel albedo). 
According to the results of the variance analysis, the effect of the addition of the orange peel albedo layer on yeast/mold count was found to be statistically significant $(p<0.01)$ while the effect of the storage time was found to be very significant $(\mathrm{p}<0.0001)$. Also, fig $\mathrm{x}$ orange, orange $\mathrm{x}$ storage interactions were statistically significant $(\mathrm{p}<0.05$; Table 10$)$. detected.

In the total coliform group bacteria count analysis during storage, no bacteria growth was

Table 9. Microbiological analysis results of fig dessert samples (log CFU/g)

\begin{tabular}{|c|c|c|c|c|c|}
\hline & \multirow{2}{*}{ Sample } & \multicolumn{4}{|c|}{ Storage Period (days) } \\
\hline & & 1 & 3 & 5 & 7 \\
\hline \multirow{12}{*}{ 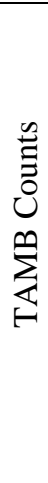 } & K1 & $3.48 \pm 0.02^{\mathrm{Db}}$ & $4.15 \pm 0.03^{\mathrm{Cab}}$ & $4.65 \pm 0.02^{\mathrm{Bab}}$ & $5.08 \pm 0.01^{\mathrm{Aa}}$ \\
\hline & U11 & $3.28 \pm 0.02^{\mathrm{Dbc}}$ & $3.57 \pm 0.03^{\mathrm{Cd}}$ & $4.26 \pm 0.05^{\mathrm{Bbc}}$ & $4.79 \pm 0.01^{\text {Aab }}$ \\
\hline & U12 & $3.60 \pm 0.08^{\mathrm{Cab}}$ & $4.12 \pm 0.03^{\mathrm{Bb}}$ & $4.51 \pm 0.05^{\mathrm{ABab}}$ & $4.78 \pm 0.04^{\mathrm{Aab}}$ \\
\hline & U13 & $3.64 \pm 0.05^{\mathrm{Cab}}$ & $4.26 \pm 0.03^{\mathrm{Bab}}$ & $4.45 \pm 0.01^{\mathrm{ABb}}$ & $4.89 \pm 0.02^{\text {Aab }}$ \\
\hline & $\mathrm{K} 2$ & $3.11 \pm 0.06^{\mathrm{Dc}}$ & $4.00 \pm 0.02^{\mathrm{Cbc}}$ & $4.74 \pm 0.11^{\mathrm{Ba}}$ & $5.14 \pm 0.03^{\mathrm{Aa}}$ \\
\hline & U21 & $3.75 \pm 0.05^{\mathrm{Da}}$ & $4.45 \pm 0.02^{\mathrm{Ca}}$ & $4.78 \pm 0.02^{\mathrm{Ba}}$ & $5.08 \pm 0.02^{\mathrm{Aa}}$ \\
\hline & U22 & $3.73 \pm 0.12^{\mathrm{Ca}}$ & $4.19 \pm 0.06^{\mathrm{Bab}}$ & $4.41 \pm 0.02^{\mathrm{ABb}}$ & $4.55 \pm 0.03^{\mathrm{Ab}}$ \\
\hline & U23 & $3.42 \pm 0.02^{\mathrm{Cb}}$ & $3.92 \pm 0.09^{\mathrm{BCbc}}$ & $4.17 \pm 0.03^{\mathrm{Bbc}}$ & $4.49 \pm 0.05^{\mathrm{Abc}}$ \\
\hline & K3 & $3.19 \pm 0.01^{\mathrm{Dbc}}$ & $4.08 \pm 0.01^{\mathrm{Cbc}}$ & $4.61 \pm 0.06^{\mathrm{Bab}}$ & $5.03 \pm 0.01^{\mathrm{Aa}}$ \\
\hline & U31 & $3.14 \pm 0.06^{\mathrm{Dc}}$ & $3.74 \pm 0.01^{\mathrm{Cc}}$ & $4.04 \pm 0.06^{\mathrm{Bc}}$ & $4.34 \pm 0.04^{\mathrm{Ac}}$ \\
\hline & U32 & $3.27 \pm 0.01^{\mathrm{Cbc}}$ & $4.08 \pm 0.03^{\mathrm{Bbc}}$ & $4.61 \pm 0.01^{\mathrm{ABab}}$ & $4.88 \pm 0.01^{\mathrm{Aab}}$ \\
\hline & U33 & $3.28 \pm 0.04^{\mathrm{Cbc}}$ & $3.78 \pm 0.02^{\mathrm{Bc}}$ & $4.22 \pm 0.04^{\mathrm{ABbc}}$ & $4.53 \pm 0.04^{\mathrm{Ab}}$ \\
\hline \multirow{12}{*}{ 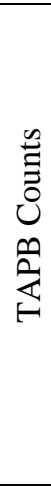 } & K1 & $2.03 \pm 0.08^{\mathrm{Cc}}$ & $3.16 \pm 0.04^{\mathrm{Bab}}$ & $3.66 \pm 0.05^{\mathrm{ABab}}$ & $4.09 \pm 0.13^{\mathrm{Aa}}$ \\
\hline & U11 & $2.79 \pm 0.04^{\mathrm{Da}}$ & $3.28 \pm 0.02^{\mathrm{Cab}}$ & $3.57 \pm 0.01^{\mathrm{Bab}}$ & $3.80 \pm 0.02^{\mathrm{Ab}}$ \\
\hline & U12 & $2.01 \pm 0.03^{\mathrm{Dc}}$ & $2.13 \pm 0.10^{\mathrm{Cc}}$ & $3.52 \pm 0.01^{\mathrm{Bbb}}$ & $3.79 \pm 0.04^{\mathrm{Ab}}$ \\
\hline & U13 & $2.76 \pm 0.02^{\mathrm{Ca}}$ & $3.27 \pm 0.07^{\mathrm{Bab}}$ & $3.46 \pm 0.01^{\mathrm{ABbc}}$ & $3.91 \pm 0.04^{\text {Aab }}$ \\
\hline & K2 & $2.32 \pm 0.02^{\mathrm{Db}}$ & $3.01 \pm 0.03^{\mathrm{Cb}}$ & $3.75 \pm 0.01^{\mathrm{Bab}}$ & $4.15 \pm 0.01^{\mathrm{Aa}}$ \\
\hline & U21 & $2.62 \pm 0.09^{\mathrm{Cab}}$ & $3.46 \pm 0.16^{\mathrm{Ba}}$ & $3.79 \pm 0.03^{\mathrm{ABab}}$ & $4.09 \pm 0.05^{\mathrm{Aa}}$ \\
\hline & U22 & $2.78 \pm 0.05^{\mathrm{Ca}}$ & $3.20 \pm 0.14^{\mathrm{Bab}}$ & $3.42 \pm 0.06^{\mathrm{ABbc}}$ & $3.56 \pm 0.06^{\text {Aab }}$ \\
\hline & U23 & $2.38 \pm 0.02^{\mathrm{Cb}}$ & $3.50 \pm 0.03^{\mathrm{Ba}}$ & $3.94 \pm 0.05^{\mathrm{ABa}}$ & $4.18 \pm 0.12^{\text {Аа }}$ \\
\hline & K3 & $2.53 \pm 0.05^{\mathrm{Dab}}$ & $3.09 \pm 0.06^{\mathrm{Cb}}$ & $3.62 \pm 0.15^{\mathrm{Bab}}$ & $4.04 \pm 0.02^{\text {Aab }}$ \\
\hline & U31 & $2.53 \pm 0.01^{\mathrm{Cab}}$ & $2.75 \pm 0.02^{\mathrm{Bbc}}$ & $3.05 \pm 0.06^{\mathrm{ABd}}$ & $3.35 \pm 0.02^{\mathrm{Ab}}$ \\
\hline & U32 & $2.77 \pm 0.01^{\mathrm{Ca}}$ & $3.09 \pm 0.03^{\mathrm{Bb}}$ & $3.62 \pm 0.03^{\mathrm{Abab}}$ & $3.89 \pm 0.01^{\text {Aab }}$ \\
\hline & U33 & $2.54 \pm 0.08^{\mathrm{Dab}}$ & $2.79 \pm 0.02^{\mathrm{Cbc}}$ & $3.24 \pm 0.05^{\mathrm{Bc}}$ & $3.54 \pm 0.01^{\mathrm{Abab}}$ \\
\hline \multirow{12}{*}{ 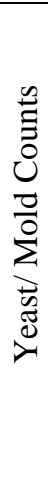 } & K1 & $3.15 \pm 0.02^{\mathrm{Bb}}$ & $4.32 \pm 0.03^{\mathrm{ABc}}$ & $4.76 \pm 0.01^{\mathrm{Abc}}$ & $4.84 \pm 0.05^{\mathrm{Ac}}$ \\
\hline & U11 & $3.27 \pm 0.02^{\mathrm{Cab}}$ & $4.51 \pm 0.01^{\mathrm{Bb}}$ & $4.83 \pm 0.08^{\mathrm{ABb}}$ & $4.95 \pm 0.04^{\mathrm{Ac}}$ \\
\hline & U12 & $3.12 \pm 0.01^{\mathrm{Dbc}}$ & $4.59 \pm 0.01^{\mathrm{Bab}}$ & $4.74 \pm 0.01^{\mathrm{ABbc}}$ & $4.97 \pm 0.02^{\mathrm{Ac}}$ \\
\hline & U13 & $3.26 \pm 0.10^{\mathrm{Cab}}$ & $4.74 \pm 0.05^{\mathrm{Ba}}$ & $5.23 \pm 0.02^{\mathrm{ABa}}$ & $5.71 \pm 0.03^{\mathrm{Aab}}$ \\
\hline & K2 & $2.65 \pm 0.04^{\mathrm{Cc}}$ & $3.90 \pm 0.07^{\mathrm{Bd}}$ & $4.28 \pm 0.02^{\mathrm{Ac}}$ & $4.51 \pm 0.04^{\mathrm{Ad}}$ \\
\hline & U21 & $3.45 \pm 0.04^{\mathrm{Ca}}$ & $4.42 \pm 0.03^{\mathrm{Bbc}}$ & $4.94 \pm 0.06^{\mathrm{ABb}}$ & $5.90 \pm 0.02^{\mathrm{Aa}}$ \\
\hline & U22 & $3.36 \pm 0.03^{\mathrm{Ca}}$ & $4.84 \pm 0.14^{\mathrm{Ba}}$ & $5.33 \pm 0.03^{\mathrm{ABa}}$ & $5.81 \pm 0.05^{\mathrm{Aa}}$ \\
\hline & U23 & $3.12 \pm 0.02^{\mathrm{Dbc}}$ & $4.61 \pm 0.02^{\mathrm{Cab}}$ & $5.09 \pm 0.03^{\mathrm{Bab}}$ & $5.58 \pm 0.06^{\mathrm{Ab}}$ \\
\hline & K3 & $3.08 \pm 0.02^{\mathrm{Dbc}}$ & $4.51 \pm 0.05^{\mathrm{Bb}}$ & $4.62 \pm 0.06^{\mathrm{ABbc}}$ & $4.74 \pm 0.01^{\text {Acd }}$ \\
\hline & U31 & $3.22 \pm 0.02^{\mathrm{Dab}}$ & $4.71 \pm 0.01^{\mathrm{Cab}}$ & $5.19 \pm 0.01^{\mathrm{Bab}}$ & $5.67 \pm 0.05^{\text {Aab }}$ \\
\hline & U32 & $3.08 \pm 0.01^{\mathrm{Dbc}}$ & $4.57 \pm 0.04^{\mathrm{Cab}}$ & $5.05 \pm 0.06^{\mathrm{Bab}}$ & $5.54 \pm 0.03^{\mathrm{Ab}}$ \\
\hline & U33 & $3.28 \pm 0.03^{\mathrm{Dab}}$ & $4.76 \pm 0.08^{\mathrm{Ca}}$ & $5.24 \pm 0.01^{\mathrm{Ba}}$ & $5.73 \pm 0.01^{\mathrm{Aa}}$ \\
\hline
\end{tabular}

TAMB: Total aerobic mesophilic bacteria, TAPB: Total aerobic psychrophilic bacteria.

a-d $(\downarrow)$ : Values with the same capital letters in the same column for each analysis differ significantly $(\mathrm{p}<0.05)$.

A-D $(\rightarrow)$ : Values with the same capital letters in the same rows for each analysis differ significantly $(\mathrm{p}<0.05)$.

According to the results of the sensory analysis, the color scores of all samples generally increased during the first 5 days of the storage period. However, color scores decreased after day 5 $(\mathrm{p}<0.05)$. During the storage period, the sample that received the lowest sensory scores was K1 whereas the sample that received the highest sensory scores was U33. 
Table 10. Variance analysis results of microbiological analysis of incir uyutmas1 samples (p* value)

\begin{tabular}{llll}
\hline Source of Variance & TAMB & TAPB & Yeast/Mold \\
\hline Figs & $0.0032^{* *}$ & $0.096 \mathrm{~ns}$ & $0.065 \mathrm{~ns}$ \\
Albedo & $0.015^{*}$ & $0.128 \mathrm{~ns}$ & $0.002^{* *}$ \\
Storage & $<0.0001^{* * *}$ & $<0.0001^{* * *}$ & $<0.0001^{* * *}$ \\
Figs x Storage & $0.458 \mathrm{~ns}$ & $0.105 \mathrm{~ns}$ & $0.067 \mathrm{~ns}$ \\
Figs x Albedo & $0.021^{*}$ & $0.032^{*}$ & $0.042^{*}$ \\
Albedo x Storage & $0.042^{*}$ & $0.765 \mathrm{~ns}$ & $0.048^{*}$ \\
Figs x Albedo x Storage & $0.816 \mathrm{~ns}$ & 0.762 & $0.064 \mathrm{~ns}$ \\
\hline
\end{tabular}

${ }^{*} \mathrm{p}<0.05,{ }^{* *} \mathrm{p}<0.01,{ }^{* * *} \mathrm{p}<0.0001$, ns: Statistically not significant.

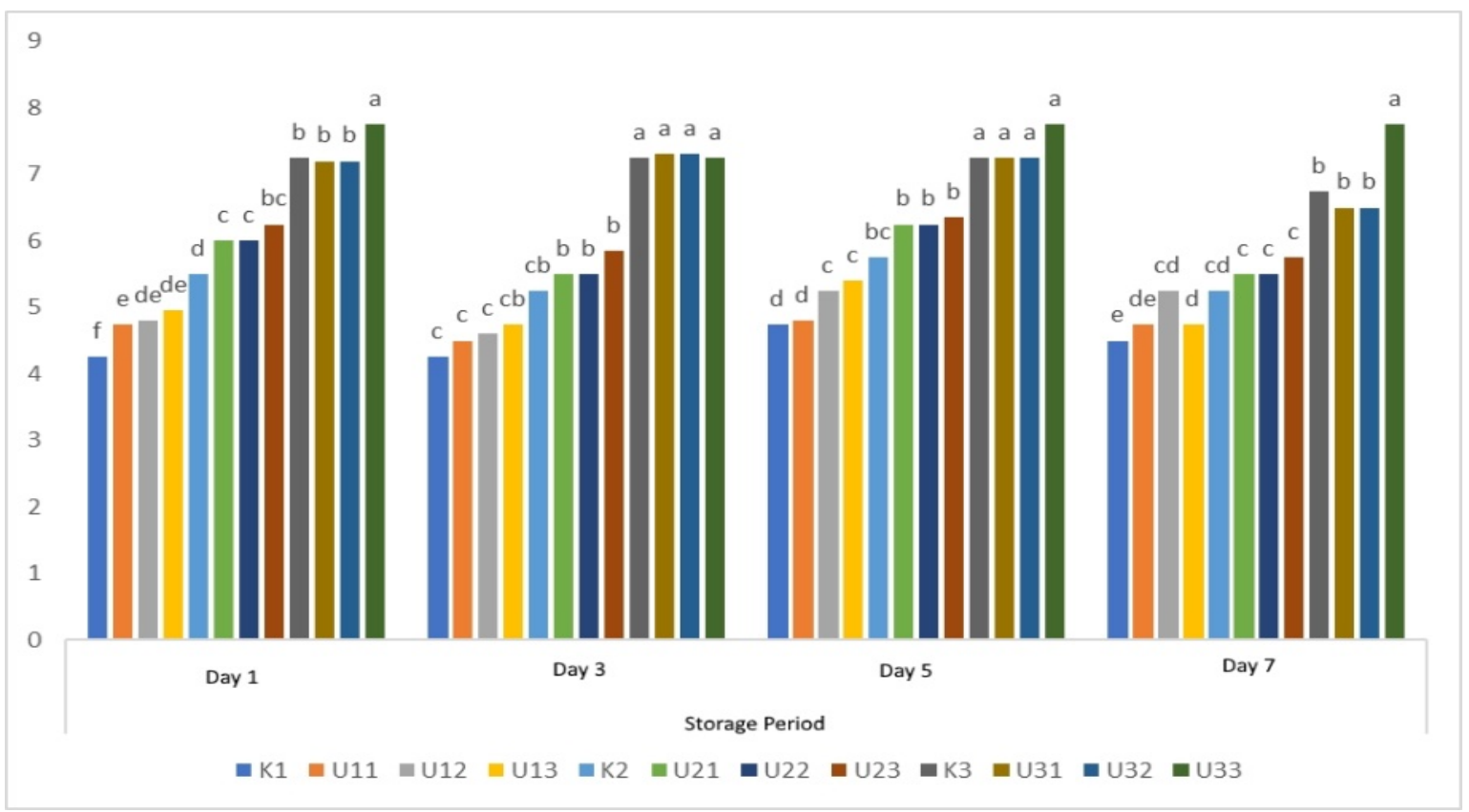

Figure 1. Sensory analysis color scores of incir uyutması samples during the storage period

As the fig ratio of increased color scores increased $(\mathrm{p}<0.05)$. The sample that received the highest color scores was U33, U32 and U31 with scores 7.75 and 7.25, respectively, on the fifth day of the storage period. In addition, the increase in the orange peel albedo ratio increased the color scores ( $<<0.05$; Figure 1). According to the results of the variance test analysis, the effect of the addition of the figs on the color scores was found to be statistically very significant $(\mathrm{p}<0.0001)$ while the effect of orange peel albedo addition was found to be very significant $(\mathrm{p}<0.01$; Table 11$)$. The aroma scores of all samples decreased during storage $(\mathrm{p}<0.05$; Figure 2$)$. In addition, the increase in the fig and orange peel albedo ratios added to the product decreased the aroma scores of the samples $(p<0.05)$. On the first day of storage, the K1 sample had the highest aroma score whereas the lowest aroma score was determined in U33. According to the results of the variance test analysis, the effects of fig addition and storage period were found to be statistically very significant $(\mathrm{p}<0.0001)$ on aroma scores. In addition, fig $\mathrm{x}$ storage interaction was found to be statistically significant $(\mathrm{p}<0.05$; Table 11$)$.

Table 11. Variance analysis results of microbiological analysis of incir uyutmas1 samples (p* value)

\begin{tabular}{lllll}
\hline Source of Variance & Color & Aroma & Texture & General Evaluation \\
\hline Figs Ratio & $<0.0001^{* * *}$ & $<0.0001^{* * *}$ & $<0.0001^{* * *}$ & $<0.0001^{* * *}$ \\
Albedo & $0.0012^{* *}$ & $0.123 \mathrm{~ns}$ & 0.231 & $0.021^{*}$ \\
Storage & 0.043 & $<0.0001^{* * *}$ & $0.002^{* *}$ & $0.012^{*}$ \\
Figs x Albedo & 0.345 & $0.342 \mathrm{~ns}$ & $0.543 \mathrm{~ns}$ & $0.213 \mathrm{~ns}$ \\
Figs x Storage & 0.213 & $0.041^{*}$ & $0.432 \mathrm{~ns}$ & $0.083 \mathrm{~ns}$ \\
Albedo x Storage & 0.121 & $0.076 \mathrm{~ns}$ & $0.213 \mathrm{~ns}$ & $0.269 \mathrm{~ns}$ \\
Figs x Albedo x Storage & 0.108 & $0.094 \mathrm{~ns}$ & $0.657 \mathrm{~ns}$ & $0.591 \mathrm{~ns}$ \\
\hline
\end{tabular}

${ }^{*} \mathrm{p}<0.05,{ }^{* *} \mathrm{p}<0.01,{ }^{* * *} \mathrm{p}<0.0001$, ns: Statistically not significant. 
It was determined that the texture scores of all fig dessert samples decreased during storage, especially the rate of this decrease increased from the 5th day of storage $(p<0.05$; Figure 3$)$. However, the increase in the ratios of fig and especially orange peel albedo added to the product increased the texture scores of the samples $(\mathrm{p}<0.05)$. In the first and last days of storage, U31, U32 and U33 samples had the highest texture scores. On the 7th day of the storage, the samples that do not contain orange peel albedo had the lowest texture scores $(\mathrm{p}<0.05)$.

In the analysis of variance test, it was determined that the effect of figs addition on the aroma scores was found to be statistically very significant $(p<0.0001)$ while the effect of the storage period was found to be very significant $(\mathrm{p}<0.01$; Table 11$)$.

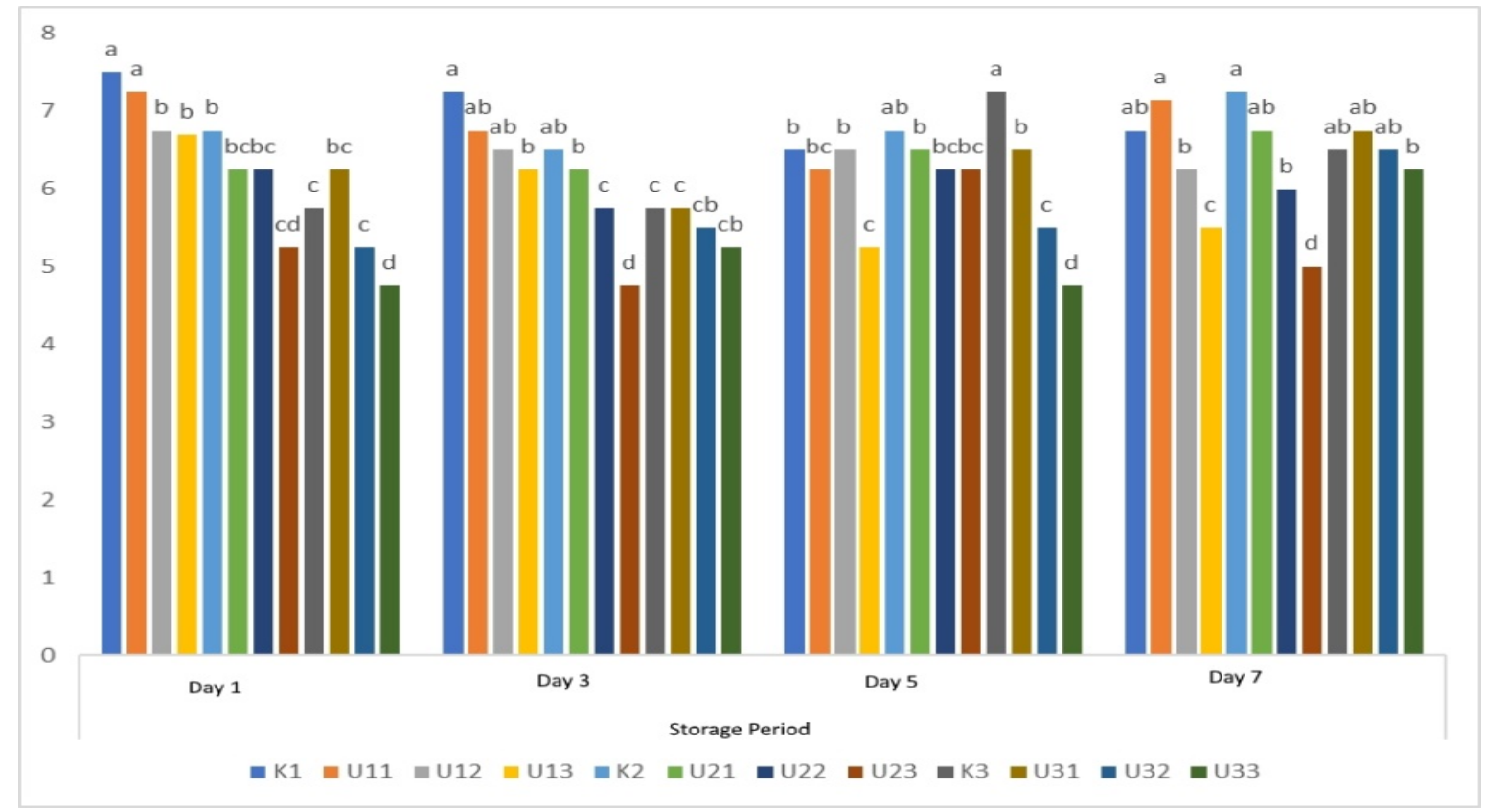

Figure 2. Sensory analysis aroma scores of incir uyutmas1 samples during the storage period

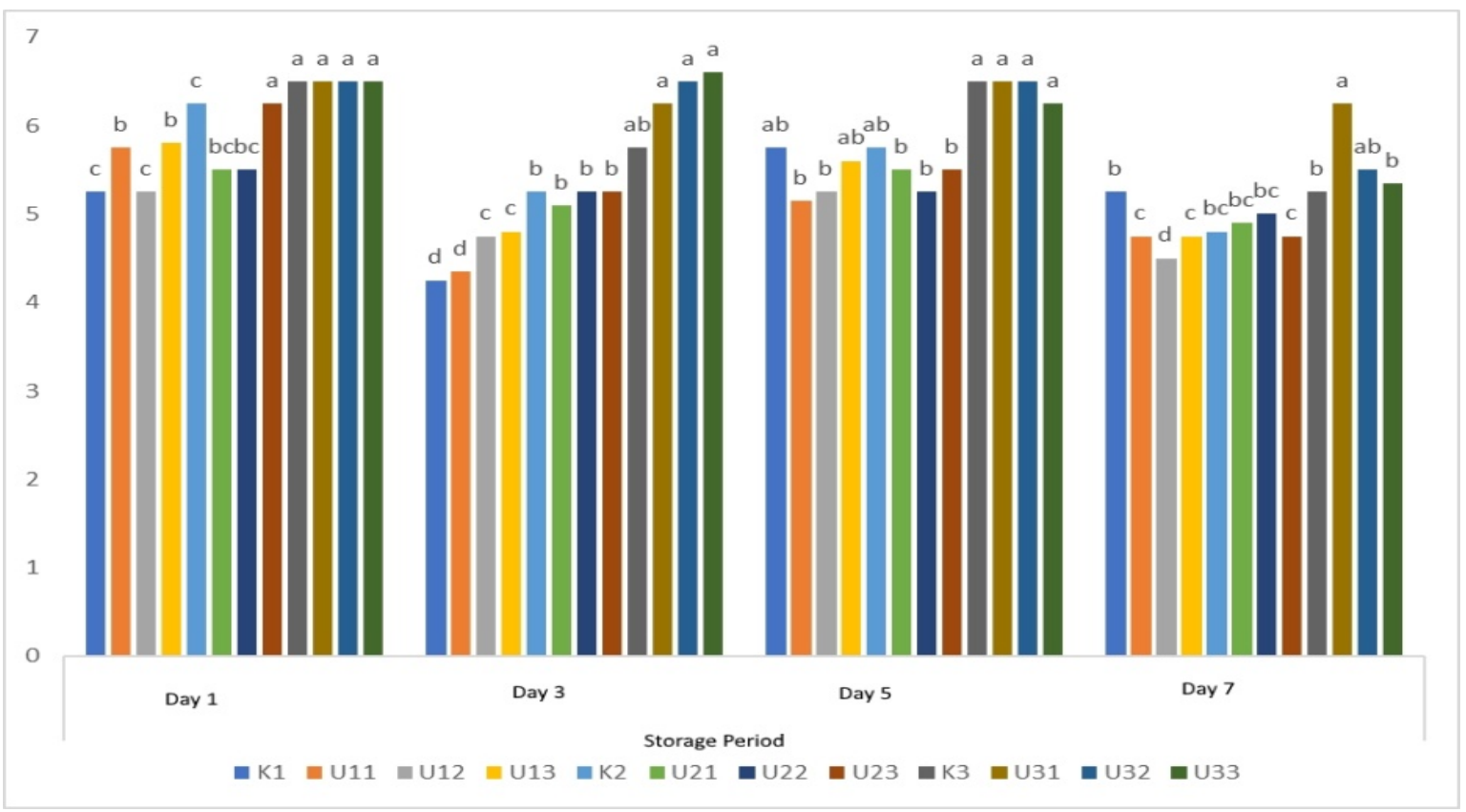

Figure 3. Sensory analysis texture scores of incir uyutmas1 samples during the storage period 
It was determined that the overall evaluation scores of incir uyutmasi samples increased during the first 5 days of storage however decreased after the 5th day $(\mathrm{p}<0.05$; Figure 4$)$. The increase in the fig and orange peel albedo ratios added to the samples increased the overall evaluation scores $(\mathrm{p}<0.05)$. The lowest overall evaluation scores were determined in the samples (K1, U11, U12, and U13) with the lowest fig ratios on the first and the last days of the storage period. The highest overall evaluation scores were determined in the samples (K3, U31, U32, and U33) with the highest figs ratios $(\mathrm{p}<0.05)$.

The effect of fig addition on overall evaluation scores was found to be statistically very significant $(\mathrm{p}<0.0001)$ while the effect of storage period and orange peel albedo addition were found to be significant $(\mathrm{p}<0.05$; Table 11$)$.

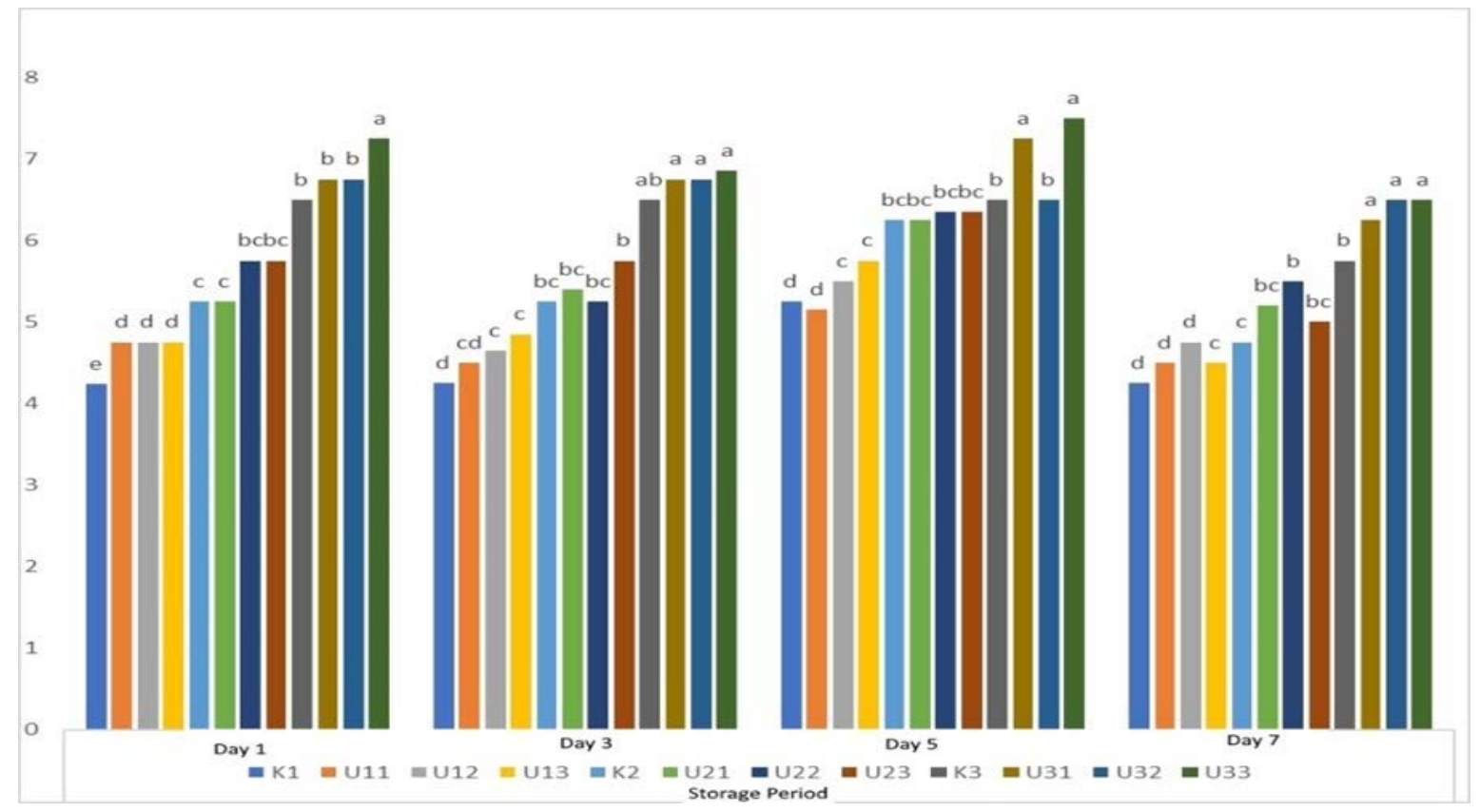

Figure 4. Overall sensory analysis scores of incir uyutmas1 samples during the storage period

\section{Conclusion}

İncir uyutması, a Turkish local dessert, has a high nutritional value and commonly consumed in the region where it is produced. It is thought that this contributed to the promotion of the dessert, and as a result, it can be produced at a wider region in a commercial sense, thus reaching a wider consumer mass and contributing to the economic value of the product.

In addition, orange peel albedo addition, an important surplus of the fruit juice industry, positively changed the general characteristics of the dessert and increased its consumption capacity.

Furthermore, obtaining plant enzymes in Turkey, purification and used commercially is not sufficient. However, to date, except for a few varieties, the use of plants has been limited due to their high proteolytic activity. It is necessary to increase the researches on the use of these low-cost plant enzymes in the industry and to carry out different studies by adding sugar to the formulation and increasing the orange peel albedo ratio in incir uyutmas1 production.

\section{References}

Akarca, G., Tomar, O., \& Gok, V. (2015). Effect of different packaging methods on the quality of stuffed and sliced Mozzarella cheese during storage. Journal of Food Processing and Preservation, 39, 2912-2918.

Akarca, G., Caglar, A., \& Tomar, O. (2016). The effects spicing on quality of Mozzarella cheese. Mljekarstvo, 66(2), 112-121. 
Anonymous. (2012). Food Technology. Making Sensory Controls. Republic Of Turkey Ministry of Education. Ankara, Turkey.

AOAC. (2016). Official Methods of Analysis (20th Ed. 981.12.). Washington, USA: Association of Official Analytical Chemists.

Atik, I. (2012). Some features of the figs dried by naturally, manufactured traditionally and industrially and the aflatoxin contents in province of Aydin. (MSc), Pamukkale University, Graduate School of Natural and Applied Sciences Denizli, Turkey.

Ayar, A., Sert, D., \& Akbulut, M. (2009). Effect of salep as a hydrocolloid on strorage stability of "İncir Uyutmas1" dessert. Food Hydrocolloids, 23, 62-71.

Ayar, A. (2013). Some properties of traditional Turkish dessert 'İncir Uyutmas1' produced by yoghurt culture. Indian Journal of Traditional Knowledge, 12(3), 370-378.

Caliskan, O. (2012). Present status and future of table fig cultivation in Turkey. Journal of Agricultural Faculty of Uludag University, 26(2), 71-87.

Gorunmezoglu, O. (2008). Investigation of antioxidant capacities of apricot and fig. (MSc), Adnan Menderes University, Graduate School of Natural and Applied Sciences Aydın, Turkey.

Halkman, K. (2005). Food Microbiology Applications. Ankara, Turkey: Başak Printing and Promotional Services.

Hut, M. (2012). Production of probiotic Incir Uyutmast dessert which has functional properties. (MSc), Sakarya University, Graduate School of Natural and Applied Sciences Sakarya, Turkey.

Hut M., \& Ayar A. (2013). Production of probiotic "Incir Uyutması" dessert which has functional properties. Sakarya University Journal of Science, 17(1), 147-153.

ISO. (1991). International standard organization, 4832. General guidance fort the enumeration of coliforms colony count technique. Geneva, Switzerland.

ISO. (2008). International standard organization, 21527-1, 2008. Microbiology of food and animal feeding stuffs, Horizontal method for the enumeration of yeasts and moulds, Part 1: Colony count technique in products with water activity greater than 0.95 .

ISO (2013a). International standard organization, 4833-1, 2013. Microbiology of the food chain, Horizontal method for the enumeration of microorganisms, Part 1: Colony count at 30 degrees $\mathrm{C}$ by the pour plate technique. Geneva, Switzerland.

ISO (2013b). International standard organization, 4833-2, 2013. Horizontal method for the enumeration of microorganisms, Part 2: Colony count at 30 degrees $\mathrm{C}$ by the surface plating technique. Geneva, Switzerland.

Kalitekin, S. (2015). Optimization and production of the instant 'Incir Uyutmasi' dessert. (MSc), Erciyes University, Graduate School of Natural and Applied Sciences Kayseri, Turkey.

Onogur, A. T., \& Elmaci, Y. (2012). Sensory Evaluation in Foods. İzmir, Turkey: Sidas Publishing.

Secim, Y. (2011). Chemical and microbiological quality of some milky sweets offered for consumption in the city center of Konya and manufactured experimentally. (MSc), Selcuk Universiy, Graduate School of Natural and Applied Sciences Konya, Turkey.

Yavıç, A., Taylan, A., Balcı, H., Encu, T. (2016). Biochemical and Pomological Characteristics of Hawthorn (Crataegus spp.) Fruits Grown in Şemdinli, Hakkari.Yuzuncu Yıl University Journal of Agricultural Scinece,26(4), 500-504. 